\title{
Individual Preference for Radio Stations in The Eastern Region of Ghana
}

Paul Adjei Kwakwa, Presbyterian University College Ghana, Ghana.

\begin{abstract}
The number of radio stations in Ghana has increased tremendously over the past few years. Residents in the Eastern region in the country do have access to radio stations in the region plus those from the Greater Accra region Thus stations in the Eastern region have to compete for listenership with other radio stations from the Greater Accra. The study aimed at finding out among others, which of the region's stations do respondents prefer to listen and what factors may influence such a decision? Using respondents conveniently sampled from a semi-rural town, Akropong-Akuapem, the district capital of the Akuapem North district, it was realized that respondents preferred radio stations in Greater Accra region to those in Eastern region. Moreover, frequency distributions and chi square test showed that factors like overall image of the station, clear reception, station heritage, news coverage, kind of programme, presenters and the status of the individual influenced the choice of radio station. Again, it was found that awareness of the programme, language used, timing of the programme and number of commercial breaks helped in the choice of radio programme one listened to.
\end{abstract}

Keywords: Radio, Consumer, Akropong-Akuapem, Ghana, 


\section{Introduction}

The radio broadcasting has become one of the major sources of information in the world. There are varieties of programmes or activities that go on the waves from radio stations including talk shows, music, drama, news, announcements and education among others that provide useful information to the listeners. The Ghanaian now has access to a number of radio stations compared the early 90s where only the state media Ghana Broadcasting Corporation (GBC) existed. Thus there are options available for every individual to choose which station to listen at any point in time. A rough check on the dial of a radio in the capital, Accra can get you about thirty different stations in the greater Accra region running variety of programmes. Similarly, there about twenty radio stations each in the Ashanti and Brong Ahafo regions. Comparatively the number of radio stations in the eastern region is small, about twelve radio stations. However, residents in this region are able to access almost all the radio stations in the Greater Accra region. Thus stations in the Eastern region have to compete for listenership with other radio stations from the Greater Accra.

The situation above leads to a number of questions like which of the radio stations do residence in the eastern region listen to at any point in time since they have access to stations in Eastern and Greater Accra regions? What factors explain why they listen to a radio station at any point in time? Also, how do they rate the radio stations and certain programmes they listen to? These are the questions the paper sought to answer by relying on the principle of consumer preference. Four major factors have been identified to influence the choice of a good by a consumer. These are cultural factors, social factors, personal factors and psychological factors (see Donthu and Gilliand, 1996; Babicz-Zielińska, 2007; Hasslinger et al, 2007; Kolter and Armstrong 2007; Munyoki and Odudoh, 2011; Ashaduzzaman et al, 2011; Abraham 2011; Idris, n.d. and Montgomery, n.d.). To ascertain the influence of these variables on the individuals preference for radio in the Eastern region of Ghana a semi rural town, Akropong-Akuapem is used as a case study.

\section{Methodology and Discussion of Results}

Akropong-Akuapem, a semi rural town, is the district capital of the Akuapem North district in Ghana. The town which is about $58 \mathrm{~km}$ from Accra, the capital of Ghana, it is located at 5.97462(latitude in decimal degree), -0.08542(longitutde in decimal degree) at an 
elevation/altitude of meters. The town has farming as the major occupation for the residence. The close-ended structured design of questionnaire was adopted. The questionnaire was administered to the individuals who were willing to answer the questionnaires. By employing a convenience sampling method, a total of 75 well answered questionnaires forming $68 \%$ of the targeted population were used. Data was analyzed using frequency distributions and chi square test with the help of SPSS.

The findings of the study revealed that $47.9 \%$ were students either at the high school or college, $46.6 \%$ were employed in the formal sector and the remaining $5.5 \%$ employed at the informal sector. The age distribution was such that majority $45.9 \%$ were aged between 16-25 years, followed by $41.9 \%$ who were between 26 and 35 years. $6.7 \%$ were between 36 and 45 and $2.7 \%$ were both at $46-55$ years and 55+ years. Apart from English which was spoken/understood by $93.2 \%$ of the respondents, the local languages that were spoken/understood by respondents were Twi with $86.7 \%$, followed by Ga with $44.7 \%$ and Ewe with $40.4 \%$. The Nzema language had the least respondents with $7.5 \%$.

\section{Likeness for Radio}

Respondents were asked to indicate their level of interest for the radio and the results are represented in the table 1 below.

Table 1: Likeness for listening to radio

\begin{tabular}{|l|l|l|}
\hline Likeness for radio & Frequency & Valid percentages \\
\hline Very much & 41 & 54.7 \\
\hline Much & 18 & 24.0 \\
\hline less & 15 & 20.0 \\
\hline Do not like & 1 & 1.30 \\
\hline
\end{tabular}

From table 1, it could be realized that $54.7 \%$ said they liked listening to the radio very much while and $1.30 \%$ said they do not like listening to the radio. Thus majority of the respondents can be said to always devote themselves to radio programmes. 


\section{Motives for Listening to Radio}

Respondents said they would listen to radio for a number of reasons such for entertainment, to aid work/studies, aid sleep, and education. The full outcome is shown in table 2 below.

Table 2: Motives for listening to the radio

\begin{tabular}{|l|l|l|}
\hline Motive for listening to radio & Frequency & Valid Percentages \\
\hline Entertainment & 53 & 70.7 \\
\hline To aid work/studies & 23 & 30.7 \\
\hline Information & 62 & 82.7 \\
\hline Aid sleep & 8 & 10.7 \\
\hline Relaxation & 27 & 36.0 \\
\hline Education & 53 & 70.7 \\
\hline
\end{tabular}

From the above table it is obvious that majority of respondents $(82.7 \%)$ listened to the radio for information. Another $70.7 \%$ would listened to entertain themselves and for education. Listening to the radio to aid one's sleep had the least $10.7 \%$ votes from respondents. As we find ourselves in the information age and the radio offers a major source of information it is not surprise that majority listened to the radio for information. A number of educative programmes are also run on the airwaves and the respondents would take advantage of that likewise entertainment.

\section{Factors Influencing the Choice of Radio}

With another objective to establish the factors that influence the respondents' preference of radio stations, a number of variables were listed and respondents were to select the extent such variables may influence their decisions. The pertinent results are presented in the Table 3.

Table 3: Factors influencing the choice of radio station

\begin{tabular}{|l|l|l|l|l|l|l|}
\hline & $\begin{array}{l}\text { No } \\
\text { extent }\end{array}$ & $\begin{array}{l}\text { Small } \\
\text { extent }\end{array}$ & Moderate & $\begin{array}{l}\text { Large } \\
\text { extent }\end{array}$ & $\begin{array}{l}\text { Very large } \\
\text { extent }\end{array}$ & Chi square \\
\hline Station overall & 18.9 & 6.8 & 25.7 & 23.0 & 25.7 & $9.243^{*}$ \\
\hline
\end{tabular}




\begin{tabular}{|l|l|l|l|l|l|l|}
\hline image & & & & & & \\
\hline Clear reception & 2.7 & 4.1 & 20.5 & 34.2 & 37.0 & $57.932^{* * *}$ \\
\hline Station heritage & 15.1 & 8.2 & 26.0 & 23.3 & 27.4 & $9.671^{* *}$ \\
\hline News coverage & 2.8 & 4.2 & 18.1 & 29.2 & 45.8 & $46.889^{* * *}$ \\
\hline $\begin{array}{l}\text { kind of } \\
\text { programme }\end{array}$ & 1.4 & 5.6 & 16.9 & 29.6 & 46.5 & $48.085^{* * *}$ \\
\hline Station presenters & 4.3 & 8.7 & 27.5 & 29.0 & 30.4 & $21.362^{* * *}$ \\
\hline $\begin{array}{l}\text { Your status as a } \\
\text { student/worker }\end{array}$ & 11.4 & 10.0 & 25.7 & 24.3 & 28.6 & $10.429 * *$ \\
\hline $\begin{array}{l}\text { Type of business } \\
\text { commercials run }\end{array}$ & 22.9 & 10.0 & 28.6 & 18.6 & 20 & 6.429 \\
\hline $\begin{array}{l}\text { Friends/colleague } \\
\text { influence }\end{array}$ & 21.3 & 23.0 & 27.0 & 20.3 & 8.1 & 7.489 \\
\hline Family influence & 20.5 & 20.5 & 28.8 & 16.4 & 13.7 & 4.740 \\
\hline Teachers influence & 24.6 & 21.7 & 23.2 & 17.4 & 13.0 & 3.101 \\
\hline Religious belief & 16.4 & 15.1 & 21.9 & 15.1 & 31.5 & 7.205 \\
\hline
\end{tabular}

$*, * *, * * *$ indicate level of significance at $10 \%, 5 \%$ and $1 \%$ respectively

The number of variables seen from table 3.1 above tell us that variables like the station overall image, clear reception, station heritage, news coverage, kind of programmes, station presenters and the status of the individual matter a lot when it comes choosing a particular radio station to listen. This is explained by the fact that these variables in the range of large extent to very large extent, received more than $55 \%$ votes from respondents. Again to find out whether differences (between observed and expected) of the result was due to chance, the chi square test was employed and the results imply that station overall image, clear reception, station heritage, news coverage, kind of programmes, station presenters and the status of the individual effect on individuals choice for a radio station were not due to chance. The other variables like kind of business commercial run, friends influence, family influence, teachers influence and religious belief did not really affect respondents choice of a radio station since the distribution is skewed towards the no extent and small extent and also they have an insignificant chi square test results. 
This means that social factors may not matter when it comes to the kind of radio station one would listen to. The finding here is contrary to the findings by Munyoki and Odudoh, (2011) that the choice of TV station was influenced by the family/group's preference. The implication is that radio stations that have carved a good image for themselves, those with good reception, nice heritage and cover in their news interesting things are likely to have a good number of listeners than those who do not have.

\section{Importance Level of Radio Programmes}

The respondents were asked to indicate the level of importance for a number of programmes and the results are tabulated below.

Table 4: Importance Level of Radio programmes

\begin{tabular}{|c|c|c|c|c|c|c|}
\hline Programmes & $\begin{array}{l}\text { Least } \\
\text { importan } \\
\text { t } \%\end{array}$ & $\begin{array}{l}\text { Less } \\
\text { importan } \\
\text { t \% }\end{array}$ & $\begin{array}{l}\text { Importan } \\
\text { t } \%\end{array}$ & $\begin{array}{l}\text { More } \\
\text { importan } \\
\text { t \% }\end{array}$ & $\begin{array}{l}\text { Most } \\
\text { importan } \\
\text { t \% }\end{array}$ & $\begin{array}{l}\text { Chi } \\
\text { square } \\
\%\end{array}$ \\
\hline $\begin{array}{l}\text { Entertainment prog. } \\
\text { like music }\end{array}$ & 5.6 & 15.3 & 25.0 & 19.4 & 34.7 & $17.813^{* *}$ \\
\hline $\begin{array}{l}\text { Current affairs prog. } \\
\text { Like News }\end{array}$ & 9.5 & 6.8 & 21.6 & 20.3 & 41.9 & $\begin{array}{l}28.432 * * \\
*\end{array}$ \\
\hline $\begin{array}{l}\text { Educational } \\
\text { programmes like } \\
\text { documentaries }\end{array}$ & 8.1 & 4.1 & 23.0 & 21.6 & 43.2 & $\begin{array}{l}35.054 * * \\
*\end{array}$ \\
\hline Sports programme & 21.6 & 21.6 & 24.3 & 8.1 & 24.3 & 6.811 \\
\hline $\begin{array}{l}\text { Inspirational/religiou } \\
\text { s programmes }\end{array}$ & 5.6 & 5.6 & 14.1 & 38.0 & 38.6 & $\begin{array}{l}37.239 * * \\
*\end{array}$ \\
\hline $\begin{array}{l}\text { Business related } \\
\text { programmes }\end{array}$ & 11.1 & 20.8 & 20.8 & 23.6 & 23.6 & 3.833 \\
\hline Health programme & 4.2 & 4.2 & 13.9 & 23.6 & 54.2 & $\begin{array}{l}61.889 * * \\
*\end{array}$ \\
\hline $\begin{array}{l}\text { Relationship } \\
\text { programme }\end{array}$ & 12.2 & 9.5 & 25.7 & 17.6 & 35.1 & $16.270 * *$ \\
\hline
\end{tabular}


The level of importance attached to radio programmes as seen from table 4 informs that apart from sports programme, all the other programmes are very important to respondents. Thus with the exception of sports programme the rest had more than $50 \%$ in the range of more important to most important. It is worthy to note that health programme alone had $54.2 \%$ considering it to be most important. The significance level of the chi square test also confirms that the variables mentioned earlier were important to respondents. This means one is more likely to listen to the radio when the programme is about entertainment, current affairs and health. Others programmes one would listen to are educative, business and inspirational/religious related. The outcome here is similar to Nwokah et al, (2009) study in Nigeria. Thus radio programmes that educate, entertain and give information about health may be regarded more important.

\section{Factors Influencing the Choice of Aired Programme}

The level of importance respondents attached to some of the programmes on radio was evaluated alongside the objective of looking at what factors may influence the choice of a radio programme. This is because a programme may be regarded as most important by a respondent but for one reason or the other he may not be able to listen to it. So respondents were asked to state the extent to which selected factors influenced their preference and the result is shown in the table 5 below.

Table 5: Factors that affect the choice of aired programmes

\begin{tabular}{|l|l|l|l|l|l|l|}
\hline Factors & $\begin{array}{l}\text { Not at } \\
\text { all }\end{array}$ & $\begin{array}{l}\text { Small } \\
\text { Extent } \\
\%\end{array}$ & $\begin{array}{l}\text { Moderate } \\
\%\end{array}$ & $\begin{array}{l}\text { Great } \\
\text { extent } \\
\%\end{array}$ & $\begin{array}{l}\text { Very Great } \\
\text { Extent } \\
\%\end{array}$ & $\begin{array}{l}\text { Chi } \\
\text { square } \\
\%\end{array}$ \\
\hline $\begin{array}{l}\text { Awareness of } \\
\text { programme }\end{array}$ & 11.3 & 11.3 & 23.9 & 21.1 & 32.4 & $11.465^{* *}$ \\
\hline $\begin{array}{l}\text { Language of the } \\
\text { programme }\end{array}$ & 4.2 & 8.3 & 30.6 & 29.2 & 27.8 & $39.000^{* * *}$ \\
\hline $\begin{array}{l}\text { Interactivity with the } \\
\text { station }\end{array}$ & 20.0 & 14.3 & 25.7 & 21.4 & 18.6 & 2.429 \\
\hline Timing of the & 9.9 & 14.1 & 26.8 & 23.9 & 25.4 & $8.085^{*}$ \\
\hline
\end{tabular}




\begin{tabular}{|l|l|l|l|l|l|l|}
\hline programme & & & & & & \\
\hline $\begin{array}{l}\text { Number of } \\
\text { commercial breaks in } \\
\text { the programmes }\end{array}$ & 21.4 & 7.1 & 18.6 & 20.0 & 32.9 & $11.714 *$ \\
\hline $\begin{array}{l}\text { Presenters of the } \\
\text { programme }\end{array}$ & 5.6 & 8.5 & 22.5 & 19.7 & 43.7 & $32.169 * * *$ \\
\hline $\begin{array}{l}\text { The guest/panel } \\
\text { members }\end{array}$ & 11.8 & 11.8 & 17.6 & 22.1 & 36.8 & $14.500 * *$ \\
\hline $\begin{array}{l}\text { Preference of other } \\
\text { students }\end{array}$ & 21.4 & 7.1 & 18.6 & 20.0 & 32.9 & 3.848 \\
\hline Influence of teachers & 20.3 & 21.7 & 30.4 & 13.0 & 14.5 & 6.580 \\
\hline $\begin{array}{l}\text { Content of the } \\
\text { programme }\end{array}$ & 12.5 & 4.2 & 23.6 & 13.9 & 45.8 & $36.889 * * *$ \\
\hline Family influence & 27.5 & 26.1 & 13.0 & 17.4 & 15.9 & 5.710 \\
\hline Friends influence & 33.3 & 23.2 & 18.8 & 8.7 & 15.9 & $11.507 * *$ \\
\hline Religious influence & 21.4 & 15.7 & 22.9 & 17.1 & 22.9 & 1.571 \\
\hline
\end{tabular}

The results from table 5 indicate that the influence of family, friends, and religious belief and interactivity with the station did not play a significant role in determining the kind of programme one would listen to on the radio. However, the rest of the variables therefore greatly influenced the choice of programme listened to as more than $50 \%$ pointed out the extent that these variables influenced them to be in the range of great and very great. That is awareness of the programme, language of the programme, guest/panel members, content of programme, time and preference of other students are may have a greater impact in determining the choice of radio programme by individuals. This is contrary to Munyoki and Odudoh, (2011). Again the significance level of the chi square test also confirms the extent that these variables influenced the choice of programme by respondents. The possible reasons to explain this is that individuals, aware of a programme are likely to make conscious effort to listen to it unlike those who are not aware. The language used for a programme also matters because no one would bother him/herself to listen to a programme he cannot understand because of the language used. 
Certain programmes may not be favourable to individuals because of the time they have been scheduled to be aired. Programmes aired late in the night may not receive greater attention compared to those done during the day time. It is therefore not surprise that a number of the political talk shows are done during the morning shows on most networks. Also, the effect of commercial breaks is that when they are many they may reduce the interest of listeners. The other influential factors, that is the presenter/host, guest/panel members of the programme and the influence of students in this study corroborates Munyoki and Odudoh, (2011).

\section{Top Three Stations}

The study again sought to find out which radio stations would be ranked as the top most three respondents like to listen. The essence is to know whether they prefer listening to stations in the Eastern region where they reside or those from the Greater Accra region. For the number one radio station Joy FM came top with $18.7 \%$ of the respondents, followed by Peace FM with $13.3 \%$ and Adom FM came third with $10.7 \%$ all in the Greater Accra region. When it came to the number two radio station, Adom FM was first with 13.3\%, Peace FM followed and Joy FM came third. The number three station saw Spring FM in the Eastern region taken the third place with $6.7 \%$

Table 6: Top three radio stations

\begin{tabular}{|l|l|l|}
\hline Number 1 & Number two & Number three \\
\hline $\begin{array}{l}\text { Joy FM (18.7\%), Greater } \\
\text { Accra, }\end{array}$ & $\begin{array}{l}\text { Adom FM (13.3\%), } \\
\text { Greater Accra }\end{array}$ & $\begin{array}{l}\text { Adom FM (12.0\%), Greater } \\
\text { Accra }\end{array}$ \\
\hline $\begin{array}{l}\text { Peace FM (13.3\%), } \\
\text { Greater Accra, }\end{array}$ & $\begin{array}{l}\text { Peace FM (12.0\%), Greater } \\
\text { Accra }\end{array}$ & $\begin{array}{l}\text { Peace FM (10.7\%), Greater } \\
\text { Accra }\end{array}$ \\
\hline $\begin{array}{l}\text { Adom FM (10.7\%), } \\
\text { Greater Accra }\end{array}$ & Joy FM (10.7\%), Greater & $\begin{array}{l}\text { Spring FM (6.7\%), Eastern } \\
\text { Region }\end{array}$ \\
\hline
\end{tabular}

The results revealed that residents of Akropong-Akuapem in the Eastern region of Ghana prefer to listen radio stations in the Greater Accra region than those within their region of residence. Thus Joy FM, Adom FM and Peace FM were selected to be the top most three 
radio stations listened to. It was only Spring FM based at the Eastern region, that could make it to the top three of the number three stations.

\section{Satisfaction for Number One Radio Station}

After the ranking there was the need to find out the satisfactory level of the number one radio stations chosen by respondents. The results shown in table 7 tells us that majority $44.4 \%$ regarded their number one station to be doing excellently well, 39.7\% regarded them to be very good and $15.9 \%$ said their number is doing good.

Table 7: Satisfaction for number one radio station

\begin{tabular}{|l|l|}
\hline Satisfaction & Valid Percentages \\
\hline Excellent & 44.4 \\
\hline Very good & 39.7 \\
\hline Good & 15.9 \\
\hline
\end{tabular}

Thus even though respondents have their own number one radio stations less than 50\% perceived that their number one station is excellent.

\section{Conclusion and Recommendation}

This study has been able to establish very important aspects about radio listening in Akropong Akuapem, a semi rural area in the Eastern region of Ghana. The findings were that majority of the respondents listened to the radio very much and they would listen to the radio for a number of reasons among which information, entertainment and education came top. The other motives for listening to the radio included to aid sleep/work, for relaxation and to aid sleep. A number of factors were found to influence the choice of radio station listened to by an individual. The most important factors determining radio choice included the overall image of the station, clear reception, station heritage, news coverage, kinds of programme, and presenters of the station and the status of the individual. Other variables like the type of business commercial run, friends influence, family influence, teachers influence and religious belief did not really affect their choice for a radio stations. Although a number of programmes are on radio, respondents have revealed that, the important ones to them were those that had to do with education, entertainment, current affairs and health issues. The rest 
were those related to business activities and inspirational /religious activities. Sports programme was not regarded all that important.

The study again has revealed that the influence of family, friends, interactivity with the station, and religious belief may not play a significant role in determining the kind of programme one would listen to on the radio. On the other hand awareness of the programme, language used, timing of the programme and number of commercial breaks helped in the choice of radio programme one listened to. At the end of the study it was revealed that respondents preferred radio stations in the Greater Accra region to the Eastern region. Notwithstanding the fact that respondents had their number one radio stations all from the Greater Accra region, less than 50\% indicated that their number one was doing an excellent work.

It is therefore recommended that programmes aired by radio stations need to take into consideration a number of factors like the timing, the guest/panel, language used, the content and the number of commercial breaks among others if managements want to catch the attention of the listeners. 


\section{References}

Abraham, K. (2011). A Study on Consumer Behaviour (With Reference To V.B Factors). International Journal of Enterprise Computing And Business Systems. Vol. 1 Issue 2

Ashaduzzaman, M., Ahmed, S.M.S and Khan, M. M.(2011). Consumer choice behavior towards mobile phone Operators in Bangladesh. International Refereed Research Journal Vol. II, Issue -4

Babicz-Zielińska, E. (2006), Role of Psychological Factors In Food Choice - A Review. Polish Journal of Food and Nutrition Sciences, Vol. 15/56, No 4, Pp. 379-384

Donthu, N. and David, I. G. (1996). The Infomercial Shopper, Journal of. Advertising Research, Vol 36 (2), 69-76.

Hasslinger, A. Hodzic, S. and Opazo, C. (2007), Consumer Behaviour in Online Shopping. Department of Business Studies, Kritianstad University,

Idris, I. (n.d.) The examination on media preferences among ethnic in Malaysia. School of Business, Sunway University, Malaysia.

Kolter, P. and Armstrong G. (2007), Principles of Marketing (12 ${ }^{\text {th }}$ edition). Upper Saddle River, Prentice Hall

Montgomery, J. (n.d.) The role that personality and motivation play in consumer behaviour: a case study on HSBC. Business Intelligence Journal

Munyoki, J.M. and Odudoh, J.A. (2011). Factors that Influence Consumer Preference of Television Stations by Public Primary School Teachers in Langata Division, Nairobi. DBA Africa management review, Vol 1 No 1, Pp 79-92

Nwokah, N. G., Amadi, N. R. and Oruene, F.M.(2009). Consumers Preference for FM Stations in Port Harcourt (A Survey of UST Students). European Journal of Scientific Research Vol.38 No.3, pp.514-520

Stávková, J., Stejskal, L. and Toufarová, Z. (2008). Factors influencing consumer behavior. Agric. Econ. - Czech, 54, 2008 (6): 276-284 